\title{
MAINTAINING BORDERS: FROM BORDER GUARDS TO DIPLOMATS
}

\author{
ALICIA ESPAÑOL, GIUSEPPINA MARSICO, LUCA TATEO
}

\begin{abstract}
The article aims at integrating the cultural psychology perspective of into the multidisciplinary field of border studies. It analyses the border phenomenon as a co-genetic system. The authors investigate the psychological side of people who relate to the border out of different motives. Then, it expands some of the theoretical concepts current in border studies by introducing psychological dimensions such as intentionality and directionality. Finally, the framework is applied to two case-studies representing the northern and southern European Union frontiers: the case of Estonian officer Eston Kohver in the Setumaa region on the Estonian-Russian border; and the experiences of border guards in the re-bordering process on the SpanishMoroccan border. It offers an innovative conceptual resource based on a triadic co-genetic epistemological approach, which allows us to overcome the binary oppositions still very present in the contemporary debates in borders studies.
\end{abstract}

Key words: borders; border guard; diplomat; cultural psychology; co-genetic logic

\section{Introduction}

Psychological sciences have not played a relevant role in border studies, so far. Border dynamics and structures have mainly been studied as socio-historical, economic and political phenomena, in which the psychological aspects were not relevant. However, the concept of the border has become extremely relevant in some areas of psychology, both from an epistemological and a methodological point of view. There is a set of studies in cultural psychology - the study of the relationship between people and culture-in which the border zone is considered to be a powerful heuristic concept for understanding many human activities. This article is an attempt to apply the current cultural psychological standpoint to border phenomena, taking into account the reciprocal organization of different levels of analysis. We argue that a dialogue between established border studies and the cultural psychology approach could foster interesting developments concerning unresolved issues in both fields. This is a theoretical article, probably not in line with large-scale empirical approaches in border studies, yet we think that our proposal cannot be easily dismissed or overlooked and that time spent reflecting on it is worthwhile. We will start by looking at some of the current theoretical concepts about borders from the cultural psychology 
perspective, such as co-genetic logic, intentionality and directionality. Then, we will conduct a "thought experiment" about two types of key actor in border dynamics: border guards and diplomats, in which we will show how they can be a useful metaphor for both psychology and border studies in shedding light on and problematizing border issues, offering new perspectives about people working on the border. Finally, we will try to apply our framework to two real case studies, Estonia and Morocco, that represent the north and southern European Union borders.

According to Balibar's "borders are everywhere" (2002) and recent attempts in the border studies have tried to improve understanding of the border to go far beyond the traditional narrow vision of state borders (Johnson et al., 2011; Rumford, 2012). We agree that the border-making process (Kolossov \& Scott, 2013; Newman, 2003) should be understood in a broader sense, and that we can detect them in our daily activities. Nevertheless, borders exist so long as they are meaningful for humans, and this is a topic of interest in cultural psychology. One can easily naturalize borders, forgetting that a border does not exist unless people are interested in it. The border and those dealing with it—both in proximity and from a distance - form a system that can only be understood as a whole.

What meaning does the border hold for the people experiencing it? What are the implications of the border for people whose mission is to maintain it? How can it be understood from a holistic perspective that takes into the account the borders, and the people who live and work there? From a cultural psychology point of view, borders are a structural component of our daily life. Thus what is of interest is how they function in the mind and in society (Valsiner, 2014). One could of course object that borders exist despite an individual having no experience of them. However, borders cannot exist without people experiencing them. So, the potential to generalize from individual psychological experience to the humanborder system lies in focusing on the people who help keep the borders functioning. In our case, we will focus on the border guards and diplomats involved in the bordering process (Johnson et al., 2011; Kolossov \& Scott, 2013; Newman, 2003). The first essential step, though, is to introduce the concepts of border dynamics as understood in the current cultural psychology research.

\section{Theoretical Aspects of Borders in cultural psychology}

During the last decade, cultural psychology has developed a theoretical view of borders as a concept for shedding light on psychological phenomena. Borders simultaneously unite and divide (Marsico, 2013; 2016). Even if the spatial metaphor is somehow reductive, borders are loci of both demarcation and contact between two or more places or things. So they could be conflicting areas and spaces of dialogue at the same time (Konrad, 2015). The "Janus-faced" nature of the border (Marsico, 2014) makes it a place of connections and oppositions because of its double function of demarcation and unification. Yet, at the same time, borders are fluid in nature (Marsico, 2013; 2016), which makes these processes ambiguous and vague.

Borders simultaneously belong to two parts, while being defined by neither one entirely (Marsico, 2013; Nail, 2016). According to Herbst's co-genetic logic (Herbst, 1976), once we draw a 'border', we immediately obtain a triplet, shown in Figure 1 with the internal element 
'inside' the border and the external element 'outside'. The simple act of drawing a circle produces a distinction in an undistinguished field or flow of events (Herbst, 1976):

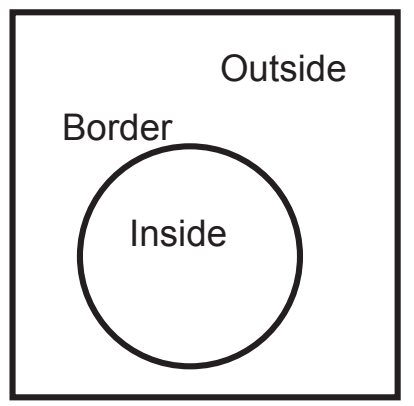

Figure 1. Modified from the original Herbst's triadic set (1976)

The elements generated as a triplet come into being together and disappear once the border is eliminated. The 'outside' is the context of the 'inside', and the border is what both separates and unifies them (Valsiner, 2014). Borders create discontinuity and connections between two related fields that acquire their signification through their relationships (Marsico, 2016). Borders emerge, exist and dissolve over time. Border dynamics are temporal, though the spatial metaphor often prevails (Tateo, 2018). The act of making a distinction therefore unifies the parts, which become a system of relations. Temporality, distinction and unification thus theoretically characterize bordering as a system of meaningful relations and represent the core of the understanding of borders in cultural psychology (Marsico \& Tateo, 2017; Tateo, 2018).

Finally, a border has a contradictory characteristic: it both reduces and heightens ambiguity (Marsico, Cabell, Valsiner, \& Kharlamov, 2013). On the one hand, borders reduce ambiguity through the act of demarcation, by limiting the space and the expected behaviour. On the other hand, since this division is neither rigid nor fixed, a space for fluidity between both sides appears, and the ambiguity re-emerges. This space for fluidity favours the conception of the border as a "space in between" (Marsico, 2011; 2014):

The space in between is neither a cuttable and divisible presence into discrete and tangible things, nor a mere "nothing" cuttable off our conceptualization, but it's a ground (for a figure) in which flow and counter-flow is a fluid interplay amid distinct bounded context takes place.

(Marsico, 2011, p.191)

Similarly it allows for the co-existence of different parts in a dialogue within the same whole (Marsico, 2014) and the emergence of a multiplicity of symbolic and material interactions (Brambilla, 2015). The in-betweenness becomes a two-sided token: the space in-between offers a richness of meaning and symbolic interactions, which require negotiation and dialogue within the parts. However, because of this richness, the ambiguity is always present, although not contemplated at first sight. 


\section{Meaning, intentionality and directionality}

Borders exist, become salient and significant, when they are meaningful to someone, for instance, when that someone intends to cross them. Even when there is in fact no-one crossing, the mere possibility (albeit remote) of an imaginary person intending to cross it to reach the other side is enough to maintain the border. In this way, borders inhabit the realm of possibility (Bruner, 1986) and are maintained in order to prevent an intentional agent intending to cross them. Dino Buzzati's famous novel, The Tartar Steppe (Buzzati, 1952), is a good example of a border which is entirely functional for the nation, even if nobody crosses it. The mere possibility that Tartars exist and may want to cross the border makes it meaningful for the State. The meaning of the border is also related to the scale of the system. Having lost its practical utility at the local level does not mean there is a loss of function at a different level, (i.e. the State and collective life order).

Directionality might also be considered meaningful in relation to the intention to cross. For instance, in March 2016, an accident occurred involving migrants in the refugee camp of Idomeni in Greece. According to reports at the time, some activists had distributed a crude map to the migrants, directing them to cross the Greek border with Macedonia by traversing the Suva River. Until that moment, the river had been considered a natural barrier of no interest to migrants, despite being part of the official frontier. But when the map was distributed, the river suddenly became a meaningful border that could be crossed to gain access to another country. In this case, the directionality (intentionality) of the actor turned the existing natural-barrier into a meaningful border. The example shows the relationship between the personal and institutional meaning of the border as defined by directionality.

People orient their actions towards a goal in a particular direction. Specifically, they project their conduct into an extended future (Valsiner, 2014). By developing and guiding their actions in such a way, humans strive to overcome a multiplicity of boundaries, in a process of constant "border crossing".

\section{Triadic co-genetic approach and psychological functions}

The border is an object that connects while dividing people, places, cultures and identities (Marsico et al., 2013). Sometimes the borders emerge as a consequence of conflict between groups, as in the UK-Ireland case, or they create conflicts as a consequence of their emergence, as in the case of the artificial partition of Kurdish areas. Once a border has been created by humans to regulate the relationships in the external world, it is also internalized, and begins to orient psychological experiences. It also becomes a psychological tool for dealing with other humans and with the environment (Valsiner, 1999). This characteristic has a direct consequence at the psychological level. Material or symbolic borders are created, maintained and demolished over time by humans, through cycles of constructive internalization and externalization, so they can regulate their conduct and manage the ambivalence in their lives (Tateo, 2016). Therefore, borders are first conceived as tools created and established by humans from the outside. Later, they are internalized (Wertsch, 1985) and regulate the psychological functioning, especially in relation to the meaning-making process and to the way relationships are built between the self, the others and the environment. 


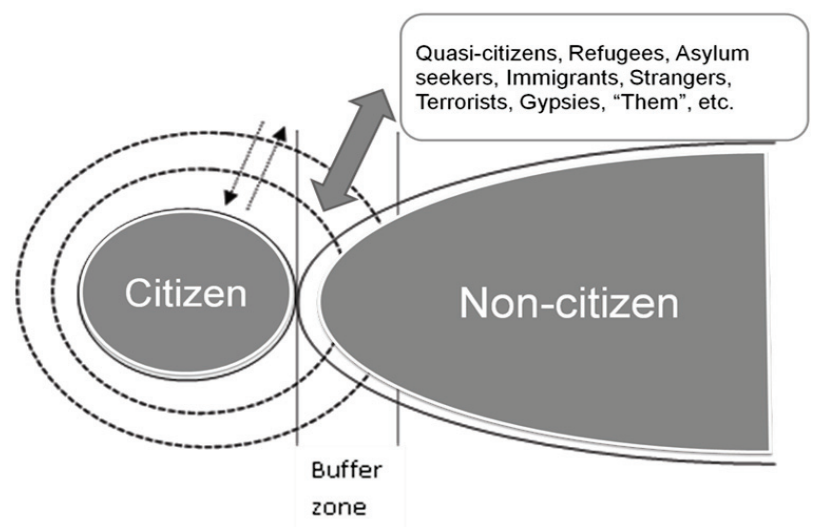

Figure 2. The boundary system citizen<>non-citizen

Borders operate in both the extra-psychological and the intra-psychological world. In the external or physical world, borders are about modifying the environment and space-time in which humans live. In the internal experience of the world, borders regulate the feelings, sense of intimacy and the definition/modification/negotiation of identities. So, even when borders are not observable, they strongly affect and guide the human experience (Marsico, 2014).

The emergence of the border zone constitutes a liminal ${ }^{1}$ system in which the different parts relate: simultaneously distinguishing and unifying. The very moment the border is defined, it mediates the person's relationship with the environment, creating a distinction in the field and in the flow of events, shaping conduct. The relationship is inherently asymmetric, to the extent that the two sides of the border do not have the same value for the person or group. This can be found on border between the Czech Republic and its neighbouring states in relation to language use in intergroup contact (Petrjánošová \& Leix, 2013). A different status is given to some languages and some uses (e.g. German vs. Czech) and by extension, to the people who speak, conditioning the relationship between groups of people and the divisions between "us" and "them".

Value depends on the directionality of the actor (Figure 2), which determines a certain degree of preference or value charging of one sub-part compared to the other. For instance, a key issue in migration phenomena and multicultural societies is the definition of citizenship. Based on the bordering process (e.g. right of birth, job contract, years of residence, tax

\footnotetext{
1 In anthropology, the notion of liminality refers primarily to a transitional phase, to a process of crossing boundaries or being on the threshold (Turner, 1977; van Gennep, 1960). According to Turner "This term, literally "being-on-a-threshold", means a state or process which is betwixt-and-between the normal, day-to-day cultural and social states and processes of getting and spending, preserving law and order, and registering structural status" (Turner, 1977). The liminal zone, as we conceive it, is the area in between or divided by borders. It is a space with its own characteristics that makes living there very specific, regulating the dynamic with the surroundings and even ways of thinking, acting and feeling (Marsico, 2016).
} 
payments, etc.) a "citizen" set is somehow defined and a value asymmetry is immediately produced (Crosby \& Rea, 2016). In classical social psychology, the statement "we as X, Y or $\mathrm{Z}$ " has a different value attached to it from "you as X, Y or Z" or "they as X, Y or Z".

Bordering immediately creates a system of meaning with a complementary "non-citizen" set—containing a number of potential instances (e.g. quasi-citizen, not-yet-citizen, foreigner, enemy, refugee, etc.). The impossibility of making clear-cut distinctions in real life produces a dynamic liminal semantic space of indeterminacy, which allows new meanings to emerge (De Luca Picione \& Valsiner, 2017; Valsiner, 2014). The buffer zone of meaning-making guides the collective development of the society toward a more limited range of possible alternatives, while maintaining a balance between the production and reproduction of social dynamics (Marsico \& Tateo, 2017). In that sense, depending on the plasticity of the border, two main developmental tendencies may emerge: a defensive process that hardens the qualities of the border, or the creation of new form of accessibility and of interactions (De Luca Picione \& Valsiner, 2017). It is, thus, possible to observe different opening/closure dynamics: from an easy exchange to a hard blockage between the two adjacent parts of the border. However, in the latter case the division produced does not merely block what is trying to cross the border, but also hampers the creation of a hybrid transition zone where the border's main function is to redistribute and connect what is divided (people, customs, norms, etc.) (Nail, 2016)

The regulation of the buffer zone is often conducted by particular actors- diplomats and border guards-whose actions modify the permeability and extension of the border zone in relation to the specific social guidance of the national governments. Border guards and diplomats are the main actors who perform the border (Johnson et al., 2011), and so we chose them as the actors in our "thought experiment" to illustrate how cultural psychology can enter into dialogue with the field of border studies. Nevertheless, we also claim that cultural psychology's focus on the systemic and procedural aspects of border phenomena can enrich the complementarity between agentive and structural approaches, as we will discuss in the next section.

\section{Meaning of the border}

What does the border mean to the people whose mission is to maintain it, and what are its implications? How can cultural psychology contribute to a richer understanding of the border from a systemic procedural perspective and account for borders and the people who live and work there as a whole?

Try now to imagine how the border guard and the diplomat both exert what we call a Minimum Power Management Position (MPMP). ${ }^{2}$ Their actions "make real" some options while inhibiting others. For example, diplomats at the consular service have the power to reject or slow down a visa application on the basis of specific requirements, and these can easily

\footnotetext{
2 Minimum Power Management Position (MPMP) is a concept recently introduced in the field of cultural psychology by Marsico and Valsiner that accounts for all the institutional function/roles in which a minimum power is used in regulating the flux of events, the course of actions and the process of decision taking. One example is the public administration worker (blue collar) at a university, municipality, tax agency etc., on whom the success or failure, speed or slowness of a bureaucratic procedure depends.
} 
change, for instance, in cases of socio-political turmoil. This example illustrates how some of the characteristics and functions of the border and their rigidity/permeability change in relation to the level of analysis. For example, at the macro level, a border established as the result of a political agreement acquires a central role in regulating the state's international relationship and the economic system of the exchange of goods and people. If we look at the micro level of the ordinary people who live on the border, we will probably find a complex of micro-actionsnegating, circumnavigating, crossing or incorporating the border into human conduct.

By introducing the personal dimension and focusing on the need to "humanize" the borderland (Brambilla, 2007; 2015), we are not "psychologizing", but accounting for the role of meaning and the consequences for the people involved in the institutional representation of the border. Humans interpret, create and modify the meaning of borders, and the signs and actions needed to establish and maintain them.

The border phenomena, the institutional roles attached, and people's conduct form a co-genetic system ${ }^{3}$ with psychological implications for the people who relate to the border for some reason. The moment a border is established (e.g. an international border between nations), two main functions emerge: maintaining it and creating a channel for contacting the "other side". These two functions are an expression of national sovereignty and therefore institutionalized by the State as two different, but complementary, border-related roles: border guards and diplomats. Let us now develop our "thought experiment" a bit further, and examine their characteristics and implications in relation to the border.

\section{The border and its guard}

Giovanni Drogo - the hero of Buzzati's novel The Tartar Steppe - is an example of a "border worker". He arrives at Fort Bastiani, an old border fortress on the edge of an endless desert, where apparently no enemy from the other side has shown up for years. What is his life at the border post like?

"It is a dead stretch of frontier," Ortiz added, "and so they never changed it. It has always remained as it was a century ago."

"What do you mean—a dead frontier?"

"A frontier which gives no worry. Beyond there is a great desert."

"A desert?"

"That's right—a desert. Stones and parched earth—they call it the Tartar steppe."

"Why Tartar?" asked Drogo. "Were there ever Tartars there?"

"Long, long ago, I believe. But it is a legend more than anything else. No one can have come across it-not even in the last wars."

"So the Fort has never been any use?"

"None at all," said the captain.

(Buzzati, 1952, pp. 12-13)

\footnotetext{
3 As described earlier, we consider border phenomena in a procedural and holistic manner, so that borders and related bounded regions are parts of the same whole that emerge, exist and disappear together.
} 


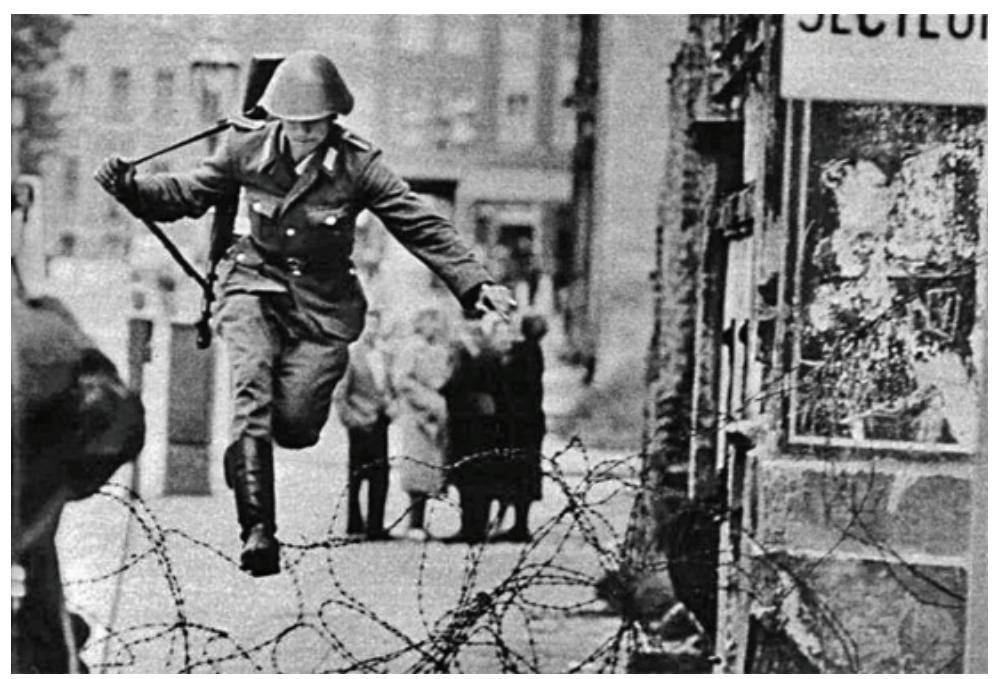

Figure 3. The Leap into Freedom (1961)

Drogo spends the whole novel waiting for someone to cross the border, who can give meaning to his job and, therefore, to his life. However, neither his life nor the border have any meaning because there is nobody (no "other") to make it meaningful. Despite no enemy ever appearing, Drogo courageously serves until the end of his life. Buzzati elegantly shows how the fate of the border guard is firmly interwoven with that of the border he is guarding.

They are so tightly interwoven that the border guard is not allowed to freely cross the border (Fig. 3).

On 15 August 1961, 19-year-old Conrad Schumann, a member of the East German state police, was sent to guard a small barbed wire fence at the corner of Ruppiner Strasse and Bernauer Strasse. At that time, two days after the Communist regime began erecting the Berlin Wall, there was just a low barbed-wire fence.

Press photographers, including Peter Leibing (Figure 3), were notified of a nervous guard at an intersection, and some were tipped off that the soldier was going to jump over the border. A West German police car pulled up near the border providing a means of escape for Schumann, who was idling as spectators shouted "Komm rüber!" ("Come over!") at him (Ross, 2016). At 4 pm on August 15, 1961, Schumann dropped his cigarette, turned around, and jumped over the coil of barbed-wire between East and West (Rare Historical Photos, 2014). At that very moment, Schumann became the first soldier to escape following the construction of the Berlin Wall. During the Wall's existence, 2,100 more soldiers would follow his path (Karacs, 1998). Those leaps are but a mere reflection of how stifling it can be living in a border zone, more precisely, living only on one side of a border.

Two considerations follow from this example. First, the border is not an event that emerges point-like in time, but is the outcome of an ontogenetic formation (and disappears) with its own temporality (Tateo, 2018). In fact, Schumann's scenario was possible because the Berlin Wall 
was erected over time, creating different conditions for crossing (or not crossing) at different moments. By contrast, the same wall was brought down in much shorter time, generating different conditions for crossing (or not crossing) in a different socio-political climate.

Secondly, the direction of the border crossing makes a difference. Schumann was running towards freedom if his act is viewed from "one side" of the border, but his act is understood in a very different way (as treason) from the "other side" of the wall. This also implies a value-addition and a value-distinction between the two parts: one acquires more value over the other (Marsico \& Varzi, 2016; Marsico, 2013).

Both the literary and real-life examples allow us to reflect on the border guard's duties in relation to political power. When the borderline is drawn, maintaining it and protecting it become essential to the nation, so border guards have a twofold goal: border making and border controlling. They are border controllers because their function is to allow people to pass, according to the established legal requirements (Crosby \& Rea, 2016; Prokkola \& Ridanpää, 2014). At the same time, they are border makers because in the act of following and reproducing these requirements they reinforce the border's existence. In other words, through their actions, the border guards make a distinction between who is allowed to cross the border. Faced inward, they are guardians of the State and help to keep it safe from undesirable "others" who want to come in. Faced outward, they are preserving the sovereignty of the State on their side of the border. Beyond this twofold mission, border guards control the potentiality to cross the border. As in the novel The Tartar Steppe (Buzzati, 1952), even if no one crosses the border, it does not lose its meaning, which is maintained at the national level, with the border guards being the symbol of the nation. In this way, border guards become the embedded border (Español, Cubero, de la Mata, \& Santamaría, 2016). The guards' uniforms invest them of the authority to perform the State's requirements, and make them portable borders. Their presence is a symbol of the border itself and therefore, they make the border even more salient.

Nevertheless, as shown by the Schuman case, the guards control the border but are the only people not allowed to cross it while on duty, for that would be a hostile act, a violation of the borders and of the national sovereignty. So, the implications go beyond guards as ordinary people. As an "embedded border", the guards must behave accordingly.

Both stories help us to understand something more about the role of border guards and how they are expected to behave, pointing out their functions and duties in relation to the State. What a border guard "can", "cannot", "must" or "ought to" do is related to his acting in the liminal zone. Thus, borders not only have repercussions at an international level, but also for the people who live in the liminal zones they create and maintain.

\section{The border and its diplomat}

While the border guard is tied to the frontier, in the case of the diplomat, the frontier is tied to his mobility. As the State protrudes into another national entity, the diplomat is another figure who emerges together with the border. In this case, the border is apparently built around the diplomat, whose double function is to simultaneously create a connection and a filter between two countries. To use an analogy from biology, the two countries act as a social membrane, making possible the formation or inhibition of channels of communication and transit. Operating under the conditions of "neutral space", diplomats are responsible 
for maintaining the border by regulating different processes. For instance, they issue visas and other travel documents (a routine consular official's job, but with a great impact on the ordinary lives of citizens across the world). They are responsible for building connections by regulating the flux of communication between the two countries and for building trust (or mistrust) via their own physical presence (their job is a very familiar and highly-valued international job on the always fragile socio-political stage).

As in the case of the border guard, the role of the diplomat has three main features. First, the diplomat emerges together with the border and is somehow bound to it (e.g. diplomats are "surrounded" by immunity yet their movements are regulated by their official function). Secondly, the process is not staccato but develops over time: diplomatic relationships are progressively "established" to different degrees and trust is built over time. Finally, depending on the direction, the diplomat is an extension of the border or a tolerated intrusion within an alien body.

In Shakespeare's Hamlet there are two marginal figure of interest to us: the warrior (Fortinbras) and the diplomat (the English ambassadors and, to some extent, Horatio) (Raffel, 2003). Their roles come at the end of the play, when Hamlet dies. Analysing the role of diplomats as historical actors, Sofer (2001) seems to confirm Shakespeare depiction of the soldier and diplomat roles:

The diplomat's service is always that of dependency. In the battle between the legate and the warrior, he is mercilessly dependent on his sovereign's actions. The diplomat is concealed from the public eye, while heads of states and generals are granted the privilege of grand gestures (Sofer, 2001, p. 110).

This happens in war, when there is no longer a border, yet there are "fronts". In ordinary times, as Neumann (2005) claims, diplomats are fundamentally agents of mediation. Diplomats, like the border guards, serve the national identity and can be seen as the embodied State as well (Prokkola \& Ridanpää, 2014) (i.e. we are not talking about a "military body" and "diplomatic body").

Inter-state relations are expressed in and by specific action, those of individuals whom I shall call symbolic, the diplomat and the soldier. Two men, and only two, no longer function as individual members but as representatives of the collectives to which they belong: the ambassador, in the exercise of his duties, is the political unit in whose name he speaks; the soldier on the battlefield is the political unit in whose name he kills his opposite number (Aron, 1966; quoted by Neumann, 2005, p. 86).

While guards look "outwards", diplomats exert their function on the other side of the border, maintaining it outside of the national territory. ${ }^{4}$ They constitute "mobile" borders: an outpost of the nation within another nation. The diplomat's function is one whereby the two sides can be connected without creating an international conflict, and it is a role both admitted and recognized by States. Diplomats are also the most fragile cells outside the national limits and in cases of international tension, dispute or conflict they are most exposed

\footnotetext{
4 This main characteristic is shared with other kinds of "border-related workers": spies, smugglers and traders.
} 
to any form of retaliation regarding their personal safety. Finally, diplomats are border regulators, as their task is to set the conditions under which borders are crossed, for mobility is generally enabled by the provision of passport services or "to extend visas" (Neumann, 2005, p. 79).

What have we learned so far through this theoretical exploration of border guards and diplomats? Borders cannot be hermetically closed, for their emergence creates the conditions under which they can be crossed (Tateo, 2016). There should be a means by which paths can be created and by which the two sides of the border can communicate. This can be achieved not only through the gates and corridors that provide the structural connection between the two sides, but through the establishment of institutional persona (Neumann, 2005). Border guards and diplomats are two complementary types of persona who facilitate this connection. Although they operate in different contexts, their functions can be understood according to the principles of co-genetic development, directionality and the regulation of conduct discussed so far.

\section{The border and its consequences}

Once the border has been delimited, it must be both maintained and crossed. At the institutional level, the border guards and diplomats have been created to perform and provide these necessary functions for the nation. They act from within the dialogical relationship from an outward-inward direction and vice versa. Guards are tied to the stability of the outward national borders, while diplomats are mobile. However, they both serve the national identity, but through different functions. Different meanings and values are produced along the inward/outward axis as the existence of the border creates an asymmetry between what is inside and what is outside. Yet the perspectives of the guard and the diplomat (i.e. their "gaze" on the two sides of the border) mediate this asymmetry and regulate the flux at the crossing. Their functions are crucial to the existence of the State itself, so fidelity and trust are key characteristics, which are always questioned and have to be ascertained (Sofer, 2001). Both diplomats and border guards are inextricably part of the establishment of international borders and are parts of the whole system. They get their meaning from the system, in the system, and because the system was created by the border. This meaning is not a given, but is a continuous temporal process in which people are collectively involved. Thus, borders cannot be understood only as physical and static limits; they exist in temporal motion (Konrad, 2015; Nail, 2016), as the bordering process is dependent on human understanding and practice (Brambilla, 2015; Johnson et al., 2011; Kolossov \& Scott, 2013; Newman, 2003; Rumford, 2012). People participate in the creation of the border and its meaning, yet it is the border itself that organizes its construction (Brunet-Jailly, 2005). On the one hand, the border acquires its meaning from the people: a line may become a border depending on the people actions, meanings and intentions. On the other hand, people elaborate meanings by her being part of the border system, as in the example of border guards and diplomats.

We have so far applied the theory of psychological borders developed by cultural psychology to "thought experiments" from border studies. The next step is to use this theoretical apparatus to ascertain whether it can help us to better understand real-life case studies. 


\section{Borders in question: Two cases studies}

In order to verify the heuristic capability of our theoretical framework, we have selected two cases from the North-Eastern and South-Western European Union frontiers. We will discuss these cases in relation to co-genetic logic and other related issues from the cultural psychology perspective on borders. The first case is the current Estonian-Russian border (Tateo, Español, Kullasepp, Marsico, \& Palang, 2018). For a long time, the Setumaa region was an internal border within the Soviet Union, and had no special meaning. But after Estonian independence, it suddenly became a crucial border, first as a national one and later as the Eastern border of the European Union. The Spanish- Moroccan border represents the Southern extent of the European Union, geographically located on a different continent. In both cases, we will show how socio-political aspects (border organization and roles) and psychological aspects (meaning-making) can be combined to propose new understandings of international bordering.

\section{Setumaa Case}

On 5 September 2014, Estonian intelligence services officer Eston Kohver was detained by the Russian FSB under disputed circumstances (Wikipedia, 2017). This created an international dispute between Estonia and Russia that was solved one year later by the exchange of two prisoners (AP News, 2015; BBC News, 2015).

The main dispute between Russia and Estonia concerned the location where Eston Kohver was detained and his actions at the moment of the incident. On the one hand, Russia declared that the officer was in fact an Estonian spy who had crossed the border with special equipment to carry out an intelligence-gathering mission, a pistol and 5,000 euros in his pocket (Wikipedia, 2017). On the other hand, Estonia has always maintained that Kohver was an officer of the Estonian Internal Security Services investigating cross border crime and smuggling, and that he had been abducted on Estonian territory while carrying out his duties (Ministry of the Interior - Republic of Estonia, 2015).

The dispute could "easily" have been solved by asking: Where does the EstonianRussian border lie in this contact zone? Where was Kohver at the moment of arrest? But, as we come to see, borders are more slippery than first thought.

In order to answer the questions and better understand the international conflict, it seems useful to locate the place where the incident took place. As the Ministry of the Interior of Estonia declared, the incident occurred in the south-eastern part of Estonia, about $8 \mathrm{~km}$ north of the border crossing at Luhamaa, in a secluded and forested area near the village of Miikse (Ministry of the Interior - Republic of Estonia, 2015).

In this area, the border is barely marked in the forest. It is easily visible and well delimited on the map thanks to virtual technology, but it is not so obvious on the ground. There is no fence or barrier marking the distinct territories. So, this is a good example of the ambivalence referred to above (Marsico et al., 2013).

As mentioned, at the very moment a border is drawn, a triadic system emerges made up of Estonia, Russia and the border between the countries. It is the border that organizes the relationship between Estonia and Russia. However, since there was no well-delimited 
border in the forested area near Luhamaa, the relationship becomes chaotic and problematic. The fuzzy border, characterized by an open transitional zone of exchange between the two countries, has to be demarcated so the relationship can be organized and a solution to the international dispute found.

In this situation, there was no infrastructure demarcating the border either, that responsibility was devolved to the border guards and the international diplomat who intervened afterwards. As we explained above border guards become a country's "sign" and so if they cross to the other side, it is seen as an infraction of international law. This was the point the Russian government made in justifying the arrest and imprisonment of the officer. The same reason was given by the Estonian government when they declared Kohver had been abducted on Estonian territory by Russian agents. In a way, in the absence of any structural mark, border-making and demarcation are devolved to the border guards.

All the actions of the Estonian diplomats who intervened afterwards in the Setumaa case were aimed at solving and diminishing the division created by the international dispute. Once the border was established, the diplomatic corps become the channel for connecting the two countries, but at the same time, the diplomats' actions reinforced the border because they represented the demands of Estonia's government.

Both strategies (reinforcing and diminishing) were carried out on the same border but under different circumstances and for political reasons. The Kohver case represents a clear dramatization of the relationship between Estonia and Russia and a hyper-generalization of the incident in terms of political relations. At the abstract level of analysis, the Kohver case shows the double function of borders: while organizing the relationship between A and B (i.e. two States, two regions, events etc) and serving the ordinary function of keeping others out (with the exception of legitimate crossers), borders simultaneously set the stage for dramatized conditions. The dramatization of the relationships between A and B could rapidly escalate and lead to suspicion of the Other. Both parts of the border (A and B) are mutually engaged in a drama of reciprocal fear (i.e. invade $<>$ being invaded), with subsequent mutual acts of dramatization and counter-dramatization. The Kohver case, then, goes beyond the illegitimate crossing of a border and sheds light on the main axis of the process of dramatization in human affairs that can easily be found, for example, in our contemporary hyper-techno society that secures "sensitive private data" while allowing free access to any other kind of personal information.

\section{Spanish-Moroccan case}

Spain, and therefore Europe, shares two land borders with the Kingdom of Morocco: the Autonomous Cities of Ceuta and Melilla. They are the only two European territories in Africa and form part of the external border of the European Union (Ferrer-Gallardo, 2008; Planet Contreras, 2004). In recent years, the borders of the two cities have become known through the important process of re-bordering they have undergone since the signing of the Schengen agreement (Castan Pinos, 2014a, 2014b; Ferrer-Gallardo, 2008). In order to stop immigration, the perimeter of the city has been fortified and equipped with high-tech surveillance systems, pushing the limits of militarization and exceeding the violation of human rights (Soddu, 2006). At the same time, the narrative of fear about the hypothetical 
invasion of immigrants has dominated not only the media, but also policymakers at the national and European level (Castan Pinos, 2014b).

Under the Schengen agreement, the two cities have differential treatment, creating a gap in the current legal conditions. Inhabitants of the Tétouan border region (in the case of Ceuta) or the Nador border region (in the case of Melilla) do not need a visa to enter these Spanish cities, provided that they do not spend the night there (Castan Pinos, 2014a; Ferrer-Gallardo, 2008). In this way, commercial and trade flows are maintained to keep the economies of the two cities afloat.

However, the intense atypical commerce generated around the Spanish- Moroccan border generates serious problems on the crossing, mainly in the morning, when many people cross for work. Crowds and shoving are common at the beginning of the workday. In addition, conflicts and disputes between Moroccans and border guards are part of everyday life at the border post.

We can extract some conclusions regarding the border guards' side from a study describing the border experiences of diverse people on Ceuta's border (Español, Cubero, \& de La Mata, 2017). Through their narratives, the border guards explain their work and perceptions of themselves and of the others they have to deal with.

First, they describe their work by referring to the actions of permitting or preventing border crossing. Then they define themselves on the basis of the actions of containment and control they have to perform at the border checkpoint. They describe their experiences of the border in terms of their professional practice. Their job is border-making, that is, filtering people according to whether they may legitimately cross. They become the embodied border when they have to shout or physically contain the crowd, and this may conflict with human rights. Fight discourses are present in the border guards' narratives especially when they refer to the action of defending the border against illegal entry. At the same time they show a sense of belonging, subscribing to the Spanish national identity and having an increased sense of preserving the European essence.

Nonetheless, it is in the border guards' representations and descriptions of "others" that the distinction is clearly shown. Among the different groups that gather on the SpanishMoroccan border (Español et al., 2017), "the other" is mainly identified in the Moroccans who cross to work in the irregular goods trade (that is, carriers and traders). The border crossing makes these people animals in the border guards' eyes. They lose all human characteristics and become mules [hammal, in Arabic] or goats. The border guards have internalized the border as a tool that allows them to do their work. The distinction created between them and Moroccans facilitates them in the execution of their duties: to control, to stop and to prohibit entry, even to hit Moroccans in the line of duty.

The re-bordering of the Spanish-Moroccan border in recent decades has had psychological consequences for the border guards. They are seen not only as border control, but also, and more so, as border-makers. They have the power to permit a person to cross; especially in the case of the Moroccan traders for whom crossing the border is not legally regulated. These workers constitute the main group crossing via the checkpoint, and so are the predominant users of the "gap" in the Schengen agreement to make their living. It is at this point that the ambiguity of the border and the border guard's Minimum Power Management Position (MPMP) emerges again. The lack of a legal definition for these 
workers creates a space in which border guards become the real makers of the rules on crossing. They have established a schedule according to which workers may cross, a schedule which is not formally stipulated in any legal document, but is based on daily routine. Indeed, the schedule can change according to the situation at the checkpoint or the mood of the border guards. Therefore, it is their actions that ultimately "make real" the border crossing. This is a perfect example of a border made by individuals-acting-through-mediation (Wertsch, 1993), and the process of border-making (Kolossov \& Scott, 2013; Newman, 2003) implies tensions and contradictions of the border itself.

\section{Conclusions}

Borders not only separate communities, but also regulate contact between them. The issue of scale dependency has become crucial for understanding the meaning of borders in our minds and in society. As we have discussed so far, nations make use of the two well-defined institutional functions for maintaining and negotiating borders: border guards and diplomats. By adopting the cultural psychology perspective, we have conceived of border, guards and diplomats as parts of the same co-genetic process. They are actors in the bordering process, becoming symbols of the State and embedding the functions of the border itself. Border guards and diplomats exist in a complementary relationship: border guards serve as the fixers of the border conditionally passing people through, while diplomats (and spies) conditionally transcend the fixed nature of the territorial borderline. A diplomat is a border guard in diplomatic attire, while the border guard is a diplomat in uniform. A diplomat, without a border guard, becomes useless to both sides (becoming a sort of potential "double spy"). When current approaches are integrated with a cultural psychological perspective, we can learn about the complexity of the phenomenon. It provides new insights into border issues, linking the micro-level to the macro-level of analysis. In this vein, Buzzati's novel The Tartar Steppe is but a hyperbole of a possible world. It constitutes an artistic attempt to figure out how living a life might be meaningless from the personal point of view but not from the national standpoint. On the other hand, the cases of Schumman and Kohver highlight some of the specific individual and socio-cultural characteristics of being a border guard and all the implications (and repercussions) of that at the personal, institutional and socio-political levels. Finally, the experiences of the border guards on the Spanish-Moroccan border show us the border-making process at the micro scale.

From the cultural psychological standpoint, borders are conceived as a way of creating distinctions in the fluid flow of events, and therefore, as a psychological tool for structuring personal relationships with the environment. The moment it is created and starts to regulate the world outside us, it is also internalized and acts to modulate our minds as well. Yet, the distinctions produced by the border-making process are not always so clear. Hence ambiguity remains a fundamental aspect of borders. The richness of the concept resides in this characteristic. The inherent ambivalence of the border creates a space for negotiation and dialogue, but also where misunderstanding and possible confusion may arise.

The cultural psychology perspective attempts a more holistic and dynamic conceptualization of borders, defined as a component of a triadic system (inside $<>$ border $<>$ outside) that emerges, exists and vanishes together. This provides us with an innovative conceptual apparatus based on a triadic co-genetic epistemological approach that enables us to overcome 
the binary oppositions still very much present in contemporary debates in the field of borders studies. $^{5}$

\section{References}

AP News. (2015). Russia, Estonia exchange 2 prisoners on border bridge. Retrieved June 3, 2017, from https://apnews.com/ef6eab748e064144b85080eb604a6245/russia-estonia-exchange-prisoners

Balibar, E. (2002). Politics and the other scene. London: Verso.

BBC News. (2015). Russia and Estonia "exchange spies" after Kohver row - BBC News. Retrieved June 3, 2017, from http://www.bbc.com/news/world-europe-34369853

Brambilla, C. (2007). Borders and identities/border identities: The Angola-Namibia border and the plurivocality of the Kwanyama identity. Journal of Borderlands Studies, 22(2), 21-38. http://doi.org $/ 10.1080 / 08865655.2007 .9695675$

Brambilla, C. (2015). Exploring the critical potential of the borderscapes concept. Geopolitics, 20(1), 14-34. http://doi.org/10.1080/14650045.2014.884561

Bruner, J. S. (1986). Actual minds, possible worlds. Cambridge, MA: Harvard University Press.

Brunet-Jailly, E. (2005). Theorizing borders: An interdisciplinary perspective. Geopolitics, 10(4), 633649. http://doi.org/10.1080/14650040500318449

Buzzati, D. (1952). The Tartar Steppe. New York: Farrar, Straus \& Young.

Castan Pinos, J. (2014a). La fortaleza europea: Schengen, Ceuta y Melilla. Ceuta: Instituto de Estudios Ceutíes. http://doi.org/10.1017/CBO9781107415324.004

Castan Pinos, J. (2014b). The conflicting aims of the European neighborhood policy and its secondary effects. Journal of Borderlands Studies, 29(2), 133-146. http://doi.org/10.1080/08865655.2014.915 703

Crosby, A., \& Rea, A. (2016). La fabrique des indésirables. Frontières dans un aéroport européen. Cultures \& Conflits, 103-104(3), 63-90. Retrieved from https://www.cairn.info/revue-cultures-etconflits-2016-3-page-63.htm.

De Luca Picione, R., \& Valsiner, J. (2017). Psychological functions of semiotic borders in sensemaking: Liminality of narrative processes. Europe's Journal of Psychology, 13(3), 532-547. http:// doi.org/10.5964/ejop.v13i3.1136

Español, A., Cubero, M., \& de La Mata, M. L. (2017). Outlining border people of the frontier zone between Spain and Morocco. Empirical and methodological questions. Revista Internacional de Estudios Migratorios, 7(3), 176-197.

Español, A., Cubero, M., de la Mata, M., \& Santamaría, A. (2017). Guarding the frontier: Being a border guard at the Spanish-Moroccan border. In ABS Europe 2016 Conference. Luxembourg.

Ferrer-Gallardo, X. (2008). The Spanish-Moroccan border complex: Processes of geopolitical, functional and symbolic rebordering. Political Geography, 27, 301-321. http://doi.org/10.1016/j. polgeo.2007.12.004

Herbst, D. P. G. (1976). Alternatives to hierarchies. Leiden, The Netherlands: Martinus Nijhoff.

Johnson, C., Jones, R., Paasi, A., Amoore, L., Mountz, A., Salter, M., \& Rumford, C. (2011). Interventions on rethinking "the border" in border studies. Political Geography, 30(2), 61-69. http://doi.org/10.1016/j.polgeo.2011.01.002

\footnotetext{
5 Acknowledgment. The authors are grateful to Jaan Valsiner for his stimulating discussion from which the idea of this paper came up and for the insightful comments on the first version of the article.

Declaration of Conflicting Interests. The authors declare no potential conflicts of interest with respect to the research, authorship, and/or publication of this article.

Funding. The authors received no financial support for the research, authorship, and/or publication of this article.
} 
Karacs, I. (1998). The leap of hope that ended in despair I The Independent. Retrieved June 4, 2017, from http://www.independent.co.uk/arts-entertainment/the-leap-of-hope-that-ended-indespair-1167101.html

Kolossov, V., \& Scott, J. (2013). Selected conceptual issues in border studies. Belgeo, 2013(1), 0-19. http://doi.org/10.4000/belgeo.10532

Konrad, V. (2015). Toward a Theory of Borders in Motion. Journal of Borderlands Studies, 30(1), 1-17. http://doi.org/10.1080/08865655.2015.1008387

Marsico, G. (2011). The "Non-cuttable" Space in Between: Context, Boundaries and Their Natural Fluidity. Integrative Psychological and Behavioral Science, 45(2), 185-193. http://doi.org/10.1007/ s12124-011-9164-9

Marsico, G. (2013). Moving between the social spaces: Conditions for boundaries crossing. In G. Marsico, K. Komatsu, \& A. Iannaccone (Eds.), Crossing boundaries (pp. 361-374). Intercontextual dynamics between family and school. Charlotte, N.C. USA: Information Age Publishing.

Marsico, G. (2014). Being on the move. How borders help to re-think identity. In S. Salvatore, J. Valsiner, \& A. Gennaro (Eds.), Multicentric identities in globalizing world. YIS yearbook of idiographic science (pp. 369-374). Charlotte, NC: InfoAge Publishing.

Marsico, G. (2016). The borderland. Culture \& Psychology, 22(2), 206-215. http://doi. org/10.1177/1354067X15601199

Marsico, G., Cabell, K. R., Valsiner, J., \& Kharlamov, N. A. (2013). Interobjectivity as a border: The fluid dynamics of "Betweenness". In G. Sammut, P. Daanen, \& F. Moghaddam (Eds.), Understanding the self and others: Explorations in intersubjectivity and interobjectivity (pp. 5165). London: Routledge.

Marsico, G., \& Tateo, L. (2017). Borders, tensegrity and development in dialogue. Integrative Psychological and Behavioral Science, 51(4), 536-556. http://doi.org/10.1007/s12124-017-9398-2

Marsico, G., \& Varzi, A. (2016). Psychological and Social Borders: Regulating Relationships. In J. Valsiner, G. Marsico, N. Chaudhary, T. Sato, \& V. Dazzani (Eds.), Psychology as a science of human being: The Yokohama Manifesto, Annals of Theoretical Psychology, 13 (pp. 327-335). Geneve, Switzerland: Springer.

Ministry of the Interior - Republic of Estonia. (2015). About Eston Kohver. Retrieved June 3, 2017, from https://www.siseministeerium.ee/en/eston-kohver

Nail, T. (2016). Introduction. In Theory of the Border (pp. 1-17). New York: Oxford University Press.

Neumann, I. B. (2005). To be a diplomat. International Studies Perspectives, 6(1), 72-93.

Newman, D. (2003). On borders and power: A theoretical framework. Journal of Borderlands Studies, 18(1), 13-25. http://doi.org/10.1080/08865655.2003.9695598

Petrjánošová, M., \& Leix, A. (2013). Languages of borderlands, borders of languages: Native and foreign language use in intergroup contact between Czechs and their neighbours. Human Affairs, 23(4), 658-679. http://doi.org/10.2478/s13374-013-0156-y

Planet Contreras, A. I. (2004). Melilla y Ceuta como regiones de destino migratorio. In B. López García \& M. Berriane (Eds.), Atlas de la inmigración marroquí en España / Taller de Estudios Internacionales Mediterráneos (pp. 386=388). Madrid: Universidad Autónoma de Madrid.

Prokkola, E.-K., \& Ridanpää, J. (2014). Border guarding and the politics of the body: An examination of the Finnish Border Guard service. Gender, Place \& Culture, 22(10), 1374-1390. http://doi. org/10.1080/0966369X.2014.970136

Raffel, B. (2003). Hamlet. The Annotated Shakespeare. New Haven and London: Yale University Press.

Rare Historical Photos. (2014). Conrad Schumann defects to West Berlin, 1961. Retrieved June 10, 2017, from http://rarehistoricalphotos.com/conrad-schumann-defects-west-berlin-1961/

Ross, H. (2016). Leap of Freedom I Picture This. Retrieved June 10, 2017, from https://sites.psu.edu/ hannahirossblog/2016/01/28/leap-of-freedom/

Rumford, C. (2012). Towards a multiperspectival study of borders. Geopolitics, 17(4), 887-902. http:// doi.org/10.1080/14650045.2012.660584 
Soddu, P. (2006). Ceuta y Melilla: gestión fronteriza, derechos humanos y seguridad. In IEMed CIDOB (Ed.), Anuario IEMed del Mediterráneo (pp. 216-218). Barcelona: IEMed - CIDOB. Retrieved from http://www.iemed.org/anuari/2006/earticles/eSoddu.pdf

Sofer, S. (2001). Being a "pathetic hero" in international politics: The diplomat as a historical actor. Diplomacy and Statecraft, 12(1), 107-112. http://doi.org/10.1080/09592290108406191

Tateo, L. (2016). Toward a cogenetic cultural psychology. Culture \& Psychology, 22(3), 433-447. http:// doi.org/10.1177/1354067X16645297

Tateo, L. (2018). Affective semiosis and affective logic. New Ideas in Psychology, 48, 1-11. http://doi. org/10.1016/j.newideapsych.2017.08.002

Tateo, L., Español, A., Kullasepp, K., Marsico, G., \& Palang, H. (2018). Five gazes on the border : A collective auto-ethnographic writing. Human Arenas, An Interdisciplinary Journal of Psychology, Culture, and Meaning, 1(1). http://doi.org/https://doi.org/10.1007/s42087-018-0010-1

Turner, V. W. (1977). Process, system, and symbol: A new anthropological synthesis. Daedalus, 106(3), 61-80.

Valsiner, J. (1999). I create you to control me: A glimpse into basic processes of semiotic mediation. Human Development, 42(1), 26-30. http://doi.org/10.1159/000022606

Valsiner, J. (2014). An invitation to cultural psychology. London: Sage Publications.

van Gennep, A. (1960). The rites of passage. Chicago: University of Chicago Press.

Wertsch, J. V. (1985). Vygotsky and the social formation of mind. Cambridge, Massachusetts: Harvard University Press.

Wertsch, J. V. (1993). Voices of the mind. A sociocultural approach to mediated action. Cambridge, Massachusetts: Harvard University Press.

Wikipedia. (2017). Eston Kohver. Retrieved June 3, 2017, from https://en.wikipedia.org/wiki/Eston_ Kohver\#cite_note-4

Universidad de Sevilla Facultad de Psicología

Psicología Experimental

C/ Camilo José Cela, s/n

41018 Sevilla

Spain

E-mail: aliciaespanol@gmail.com

Department of Humanities

Faculty of Artt and Education

University of Salerno

Via Giovanni Paolo II, 132 - 84084

Fisciano (SA)

Italy

E-mail: gmarsico@unisa.it

The Faculty of Humanities

Department of Communication and Psychology

Aalborg University

Aalborg

9220

Denmark

E-mail: luca@hum.aau.dk 